\title{
Employee attitudes towards corporate social responsibility: a study on gender, age and educational level differences
}

\author{
Rosati, Francesco; Costa, Roberta; Calabrese, Armando; Pedersen, Esben Rahbek Gjerdrum
}

Published in:

Corporate Social Responsibility and Environmental Management

Link to article, DOI:

$10.1002 /$ csr. 1640

Publication date:

2018

Document Version

Peer reviewed version

Link back to DTU Orbit

Citation (APA):

Rosati, F., Costa, R., Calabrese, A., \& Pedersen, E. R. G. (2018). Employee attitudes towards corporate social responsibility: a study on gender, age and educational level differences. Corporate Social Responsibility and Environmental Management, 25(6), 1306-1319. https://doi.org/10.1002/csr.1640

\section{General rights}

Copyright and moral rights for the publications made accessible in the public portal are retained by the authors and/or other copyright owners and it is a condition of accessing publications that users recognise and abide by the legal requirements associated with these rights.

- Users may download and print one copy of any publication from the public portal for the purpose of private study or research.

- You may not further distribute the material or use it for any profit-making activity or commercial gain

- You may freely distribute the URL identifying the publication in the public portal 


\title{
Employee attitudes towards corporate social responsibility: a study on gender, age and educational level differences
}

\author{
Francesco Rosati ${ }^{1, *}$, Roberta Costa ${ }^{2}$, Armando Calabrese ${ }^{2}$, Esben Rahbek Gjerdrum Pedersen ${ }^{3}$ \\ ${ }^{1}$ Department of Management Engineering, Technical University of Denmark, Denmark \\ ${ }^{2}$ Department of Enterprise Engineering, University of Rome Tor Vergata, Italy \\ ${ }^{3}$ Centre for Corporate Social Responsibility, Copenhagen Business School, Denmark \\ *corresponding author: frro@dtu.dk
}

\begin{abstract}
Previous studies show that individual characteristics can influence stakeholder attitudes towards corporate social responsibility (CSR). This study analyses employee attitudes such as CSR demandingness, trust and satisfaction, to determine whether they vary according to differences in gender, age, and educational level. The analysis was carried out by surveying 153 employees of 11 Italian banks, and by performing a content analysis of the banks' sustainability reports. The Italian banking sector was chosen because of recent financial and CSR scandals. The findings suggest that, on average, male employees are slightly more trustful in and satisfied with CSR performance than their female counterparts. Graduates are slightly more demanding, largely more trustful and generally more satisfied than non-graduates. Interestingly, the difference between older and younger employees is not significant. The proposed approach can be useful in designing tailored CSR activities and communication avenues by shedding light on employees’ CSR attitudes.
\end{abstract}

\section{Keywords}

CSR attitudes, CSR perceptions, CSR expectations, Italian bank employees, Sustainability report, Content analysis. 


\section{Introduction}

In 2011, the European Commission defined corporate social responsibility (CSR) as "the responsibility of enterprises for their impacts on society" and encouraged enterprises to "have in place a process to integrate social, environmental, ethical human rights and consumer concerns into their business operations and core strategy in close collaboration with their stakeholders" (European Commission, 2011, p. 6). As such, it is not only external stakeholders that demand a high CSR performance of companies (González-Benito and González-Benito, 2010), but the internal stakeholders and employees themselves, too (Brunton et al., 2017). Therefore, it is increasingly important for companies to satisfy their employees' CSR expectations and, in turn, earn their trust (Hansen et al., 2011). The authors of the current study build on the aforementioned definition of CSR to analyse the attitudes of employees, who are, in this context, considered as internal key stakeholders. This study will also expand on the existing research, which has shown, on the whole, that stakeholders with different individual characteristics (such as gender, age, and educational level) can also experience different levels of CSR perceptions and expectations, and, more generally, CSR attitudes (e.g. Alonso-Almeida et al., 2015; Burton and Hegarty, 1999; Lämsä et al., 2008).

Thus, the aim of this study is first to investigate employee attitudes towards CSR (see also Bolton et al., 2011; Law et al., 2017; Michailides and Lipsett, 2013; Singhapakdi et al., 2015) and, second, to explore whether employees belonging to different gender, age, and/or educational level groups also experience different levels of CSR attitudes, such as demandingness of, trust in and satisfaction with CSR.

This research is carried out by examining 11 Italian banks. The Italian banking sector is particularly interesting for such an analysis because of recent financial scandals, which have been heavily criticised by institutions, scholars and customers, as well as society as a whole.

The following section reviews and discusses the existing literature on the influence of individual characteristics on CSR attitudes, perceptions and expectations, and presents the concept of demandingness, trust and satisfaction regarding CSR. Section 3 presents the research method and dataset, and Sections 4 and 5 provide the results of the study and their discussion. The final sections present a summary of the study conclusions (Section 6), and the limitations and recommendations for future studies (Section 7). 


\section{Literature Review}

\subsection{Employee attitudes towards CSR}

In order to develop and improve dialogue with increasingly demanding stakeholders (and employees), increase stakeholders' satisfaction and gain stakeholders' trust, growing numbers of companies now disclose their CSR commitment by means of sustainability reports, websites and other CSR communication activities (Capriotti and Moreno, 2007; Kolk and Pinkse, 2010; Perrini, 2005; Pollach, 2003). Moreover, employees (as internal stakeholders) are also exposed to internal CSR communication (Brunton et al., 2017; Du et al., 2010; Onkila, 2015; Seele and Lock, 2015). Effective internal CSR communication allows companies to better understand and influence their employees' perceptions (Brunton et al., 2017) by improving engagement, commitment and advocacy (Du et al., 2010; ter Hoeven and Verhoeven, 2013), which ultimately creates new opportunities for innovation and growth (European Commission, 2011).

By disclosing its CSR efforts (both externally and internally), a company thus has the opportunity to improve employee perception of CSR performance, resulting in a higher likelihood that employees meet the company's expectations.

In this study, based on a comparison between company CSR disclosure (D), employee CSR expectations (E) and employee CSR perceptions (P), we define three types of employee CSR attitudes: CSR demandingness, CSR trust and CSR satisfaction (Figure 1). In the following three subsections, the three employee CSR attitudes are illustrated, and for each, the relationship between CSR disclosure, expectations and perceptions will be investigated.

\subsubsection{CSR demandingness}

Previous studies have found that employees are very demanding in terms of labour practices and working conditions (Abel and Ittermann, 2003), human rights (Chauhan and Chauhan, 2008), equal opportunity (Bosch and Knuth, 2003), environmental impacts (Arvidsson and Carlén, 2012), and 
transparency of CSR disclosure (Lawal et al., 2017). Underestimating the importance of employee opinion can cause discontent and strikes (Gabbatt, 2012), with negative impacts on labour productivity (Bhatnagar, 2007), corporate image and reputation (Chan et al., 2013), as well as economic performance (Kramer and Vasconcellos, 1996). Thus, it is increasingly important for companies to assess and monitor the level of employees' CSR demandingness - understood here as the attitude of being demanding in terms of CSR. The authors of this study define employee CSR demandingness as the extent to which an employee expects and demands economically, environmentally and socially sustainable conduct from his/her company. This definition is inspired by studies on customer demandingness (e.g. Li and Calantone, 1998; Wheelwright and Clark, 1992), and has been adapted to the academic domain of CSR. Indeed, in accordance with $\mathrm{Li}$ and Calantone (1998), customer demandingness is determined by the level of customer requirements for the product performance. Customer demandingness thus reflects the gap between customer expectations and the product/service on offer (Gupta et al., 1986; Wang and Netemeyer, 2002).

Similarly, the level of employee CSR demandingness intrinsically depends on both employee expectations of CSR and the CSR performance of the company. Indeed, an employee who expects a CSR performance that is lower than the CSR performance disclosed by the company cannot be defined as a demanding one. Thus, analytically, employee CSR demandingness can be defined as the difference between employee CSR expectations (E) and the CSR performance disclosed by the company (D).

\subsubsection{CSR trust}

By optimising their CSR, companies can also build long-term employee trust (European Commission, 2011; Sanchez-Hernandez and Grayson, 2012). Indeed, according with Hansen et al. (2011, p. 33), employee trust is an "outcome of organizational CSR perceptions that may shape employee attitudes and behaviors". Employee trust, in turn, is found to be positively related with employee organisational citizenship behaviour (Dirks and Ferrin, 2001) and employee commitment (Farrell, 2003; Morgan and Hunt, 1994). Moreover, it has been found that trust can have a significant positive influence on stress management strategies (Yu, 2009). High levels of trust can thus help to create an innovative and growthoriented environment (European Commission, 2011). Conversely, a lack of employee trust can have a negative effect on openness in communication (Probst and Raisch, 2005), and increase absenteeism and 
turnover (Hemdi and Nasurdin, 2007; Tzafrir and More, 2006; Zemke, 2000). This study focuses on employee trust in company CSR performance (employee CSR trust), which is defined as the employee perception that the company is at least as economically, environmentally and socially sustainable as it claims to be. Thus, analytically, employee CSR trust can be defined as the difference between employee CSR perceptions (P) and the CSR performance disclosed by the company (D).

\subsubsection{CSR satisfaction}

As widely reported in CSR literature, a strong CSR orientation can enhance employees' job satisfaction (e.g. Bauman and Skitka, 2012; Martinuzzi, Gisch-Boie, and Wiman, 2010; Vlachos et al., 2013), which can have, in turn, a positive impact on: (i) employees' motivation and performance at work (Judge et al., 2001), (ii) organisational commitment (Koh and Boo, 2004), and (iii) employees' loyalty and turnover level (Fisher and Locke, 1992; Zhu et al., 2014). However, to the authors' knowledge, CSR literature does not provide any insight into employee satisfaction in terms of CSR performance. Thus, this study also aims to investigate employee CSR satisfaction, which is defined as the employee's perception that his/her CSR expectations and desires are being fulfilled and gratified by the CSR performance of his/her company.

Analytically, employee CSR satisfaction can be defined as the difference between employee CSR perceptions (P) and employee CSR expectations (E). This definition is borrowed from studies on service quality (e.g. SERVQUAL model), which measure customer satisfaction as the gap existing between customer perception and customer expectation (e.g. Pakdil and Harwood, 2005; Parasuraman et al., 1988).

\subsection{The influence of individual characteristics on employee CSR attitudes}

This section reviews the scientific literature on the influence of individual differences on employee CSR demandingness, trust and satisfaction, which are themselves attitudes dependent on employee perceptions and expectations of CSR. Recent decades have opened up a lively debate on whether (and if 
so, how) stakeholder CSR attitudes, perceptions and expectations can be influenced by individual differences, such as gender, age and educational level.

Insert Figure 1 about here

\subsubsection{Gender differences}

According to the gender socialisation approach, women and men have different attitudes, values and psychological characteristics. Thus, employees' moral orientation, as well as the outcome of certain decisions and practices, may be influenced by gender (Prasad et al., 1998; Simga-Mugan et al., 2005).

Several CSR studies on gender differences argue that women are more ethically responsible than men, and tend to act more sustainably (Alonso-Almeida, 2013; Aouina Mejri and Bhatli, 2014; Marz et al., 2003). Focusing on the Spanish tourism industry, Alonso-Almeida (2013) found that female restaurant managers are more likely to adopt practices aimed at saving water and energy. Jizi (2017) revealed that female participation on boards favourably affects engagement in and the reporting of CSR, as well as the establishment of ethical policies. Women on boards can also positively affect sustainability reporting at country level (Fernandez-Feijoo et al., 2014a). This is in line with eco-feminist theories, which claim that women are more respectful of environmental conservation needs (e.g. Agarwal, 1992; Perkins, 2007; Veuthey and Gerber, 2010). In this regard, Shiva (1988) argued that women have higher perceptions in terms of ecological degradation and adopt practices and behaviours that are more socially and environmentally responsible and sustainable. Through their analysis of the CSR perceptions and expectations of 908 Italian customers, Calabrese et al. (2016) found that there is a small substantive difference between women's and men's average expectations, with women showing higher average values than men. Thus, based on previous research, the authors of this study hypothesise that CSR demandingness can also vary for different gender groups, with women being, on average, more demanding than men.

In terms of CSR satisfaction, Panwar et al. (2010) examined students' perceptions of social responsibility within the context of the US forest products industry, and found males to be more satisfied 
than females that such an industry was fulfilling its socio-environmental responsibilities. Moreover, Smith and Kumar (2013) found men to be more strongly affected by CSR initiatives than women. These two studies seem to suggest that CSR satisfaction and CSR trust can be, on average, higher for men than for women.

Conversely, Kidwell et al. (1987) found that male and female managers do not differ in their perception of what is ethical and what is unethical. Moreover, they found that each gender views the opposite sex as more unethical than their own. In general, the scientific literature does not seem to provide a coherent answer as to the overall variation of CSR attitudes in terms of different gender groups. Thus, new research is needed on the topic of gender differences in employees' CSR attitudes. In order to fill this gap, the current study aims to verify three research hypotheses, which are proposed as follows (Table 1):

$H_{1 a}$ : Female employees have, on average, a higher CSR demandingness than male employees.

$H_{1 b}$ : Female employees have, on average, a lower CSR trust than male employees.

$H_{1 c}$ : Female employees have, on average, a lower CSR satisfaction than male employees.

\subsubsection{Age differences}

Previous research shows that age can affect cognitive processes (Cho and Hu, 2009; Hemingway and Maclagan, 2004; Quazi, 2003) and the ability to process information (Morris and Venkatesh, 2000). Moreover, aging can be accompanied by changes in attitudes, values, and lifestyles (Cho and Hu, 2009).

In particular, existing research shows that age can affect individual perceptions and attitudes towards CSR (e.g. Coutinho et al., 2017; Perryer and Jordan, 2002; Quazi, 2003; Ruegger and King, 1992). For example, Ruegger and King (1992) attempted to determine whether age played a role in the way in which 2,196 business students perceived proper ethical conduct. Their results suggest that age is a determining factor in making ethical decisions. In particular, students who fell in the 40+ age group were found to be the most ethical (i.e. the most demanding in terms of ethical behaviour), followed in order by the 31-40 group, the 22-30 group and those of 21 years of age and under.

Concerning CSR satisfaction and trust, Cho and $\mathrm{Hu}$ (2009) revealed that younger people are generally more satisfied and confident with company services than older ones, and that aging is linked to an 
increase in cynicism and distrust. In their study based on the CSR perceptions of 546 Generation Y Canadians, Mang and Piper (2013) found that, while an individual's age alone was not a significant influencing factor, an individual's age enhanced, or reduced, the effect that both higher educational attainment and greater full-time work experience had on their CSR views. Such an effect, in the authors’ opinion, indicates that the relationship between age and attitudes towards the triple bottom line is more complex than initially assumed.

On the other hand, other scholars (Eweje and Brunton, 2010; Gholipour et al., 2012; Laroche et al., 2001) have not found significant and coherent evidence to support the notion that age has a significant impact on the topic at hand.

Thus, new research is needed on the impact of age on employee CSR attitudes, and the second three research hypotheses are proposed as follows (Table 1):

$H_{2 a}$ : Younger employees have, on average, a lower CSR demandingness than older employees.

$H_{2 b}$ : Younger employees have, on average, a higher CSR trust than older employees.

$H_{2 c}$ : Younger employees have, on average, a higher CSR satisfaction than older employees.

\subsubsection{Educational differences}

Previous studies on CSR and business ethics argue that education can influence attitudes, perceptions and expectations (e.g. Dellaportas, 2006; Elias, 2004; Luthar et al., 1997). In particular, Elias (2004) revealed that a business ethics education can have a positive influence on students' attitudes, awareness, and expectations regarding CSR. Luthar et al. (1997) found that taking a business ethics course can influence students' business ethics perceptions, and that taking such a course during the earlier stages of a Bachelor programme can maximise its impact. Dellaportas (2006) claimed that a course on accounting ethics can positively influence students' ethical perceptions, thus enabling graduates to manage and solve a range of ethically ambiguous issues. Researchers have also demonstrated that people with a higher level of education develop more elaborate CSR perceptions (Quazi, 2003) and exhibit a greater CSR orientation (Kelley et al., 1990) than those less educated.

Furthermore, Sobczak et al. (2006) found that both educational level and orientation of education determine attitudes and perceptions towards CSR. In some cases, business programmes favouring the 
culture of profit maximisation produce students that give less importance to sustainability issues (Lämsä et al., 2008; Piper et al., 2012), and thus have lower CSR expectations. In this regard, Lämsä et al. (2008) found that the importance of the shareholder model grows as a result of business education, while the importance of equal-opportunity employment decreases. Comparing business students with non-business students, Piper et al. (2012) found that business students are more likely to behave in a manner that ignores human wellbeing and environmental sustainability, in favour of the pursuit of profit maximisation.

However, according to other studies, educational level does not seem to have an impact on CSR attitudes. For example, Pérez and Rodríguez del Bosque (2013) found that educational level does not have an influence on the formation process of CSR perceptions among banking customers in Spain. Similarly, Akman (2011), in a study based on 500 Turkish employees, claimed that educational level is not a significant determining factor when it comes to business ethics perceptions.

Thus, even though CSR literature seems to suggest that education, in some circumstances, can have an influence on CSR attitudes, perceptions and expectations, it is important that the present study attempts to better understand how differences in education are linked to employee demandingness, trust, and satisfaction regarding CSR. The final three research hypotheses are proposed as follows (Table 1):

$H_{3 a}:$ Graduate employees have, on average, a higher CSR demandingness than non-graduate employees.

$H_{3 b}$ : Graduate employees have, on average, a higher CSR trust than non-graduate employees.

$H_{3 c}$ : Graduate employees have, on average, a higher CSR satisfaction than non-graduate employees.

Insert Table 1 about here 


\section{Method and dataset}

The proposed method provides a systematic assessment of employee CSR attitudes (i.e. demandingness, trust and satisfaction) by means of pairwise comparisons between the three variables:

1. "CSR disclosure" (D), meaning the CSR commitment disclosed to employees by the company;

2. "CSR expectations" (E), meaning the CSR commitment that employees require from the company;

3. "CSR perceptions" (P), meaning the CSR commitment of the company, as perceived by its employees.

As described in Section 2, employee CSR attitudes are defined by the gap between CSR expectations, perceptions and disclosure. In particular, employee demandingness of CSR corresponds to the difference between CSR expectations and CSR disclosure (E-D), employee trust in CSR relates to the difference between CSR perceptions and CSR disclosure (P-D), and employee satisfaction in CSR is related to the difference between CSR perceptions and CSR expectations (P-E).

This approach is in line with previous studies on service quality (e.g. SERVQUAL model), which measure the gap existing between two variables (e.g. perception vs expectation) rather than directly measuring a specific variable (e.g. satisfaction) (e.g. Pakdil and Harwood, 2005; Parasuraman et al., 1988).

The current study uses the Global Reporting Initiative’s (GRI) Sustainability Reporting Guidelines G3.1 (Global Reporting Initiative, 2011) as the basis for measuring D, E and P (see also Bouten et al., 2011; Farneti and Guthrie, 2009; Lamberton, 2005). The GRI is a widely recognised, structured framework for CSR reporting, subdivided under three sustainability dimensions: economic, environmental and social, with the social dimension further divided into four sub-dimensions, namely labour practices and decent work, human rights, society and product responsibility (see also Bouten $e t$ al., 2011; Fernandez-Feijoo et al., 2014).

Each aspect of the company's CSR is analysed by means of GRI dimensions, sub-dimensions, aspects and indicators. The proposed method utilises the GRI indicators to create a series of "CSR items", which are composed of individual indicators or groups of homogenous indicators that describe different characteristics of the same CSR topic (Table 2) (see also Calabrese et al., 2015). For example, as seen in Table 2, the CSR item "market presence", under the GRI "economic" dimension (EC), is reported by indicators EC5, EC6, and EC7, which all describe the company's commitment to developing the local 
economic system in a sustainable manner.

Insert Table 2 about here

\subsection{Content analysis}

The CSR commitment disclosed by the company (D) was evaluated by means of content analysis. Content analysis is a research method for the standardised evaluation of textual information (Krippendorff, 2004; Neuendorf, 2002; Weber, 1990). It has been widely used to analyse and discover patterns in CSR reporting (Bouten et al., 2011; Dangelico, 2015; Guthrie and Abeysekera, 2006). The authors of this study follow the coding structure for content analysis in the form of a tree, as shown in Calabrese et al. (2015), which is characterized by the hierarchical structure of CSR dimensions, subdimensions, and items, as illustrated in Table 2. The use of a hierarchical approach minimises confusion concerning criteria and reduces disagreement among individual coders (Krippendorff, 2004). As reported by Calabrese et al. (2015, p. 317), “[t]he coding tree consists of two layers: 1) content and 2) judgements”. The “content layer” is subdivided into two levels: 1a) the CSR dimensions/sub-dimensions, and 1b) the CSR items described in Table 2. For example, when the coders assess the CSR item "market presence” of the economic CSR dimension, they first associate content elements with the economic dimension, and then to the CSR item “market presence”. Next, as described by Calabrese et al. (2015, p. 317), "the coders assign a value to each CSR item on a Likert scale from 1 to 5, based on their judgement of the degree of commitment” that the company “expresses concerning that particular CSR item”.

\subsection{Questionnaire}

CSR expectations (E) and perceptions (P) of bank employees were assessed through a questionnaire to collect their judgements on each CSR item.

To illustrate the questionnaire structure, the example of the CSR item "market presence” (GRI indicators EC5+EC6+EC7, see Table 2) is provided below: 
- Question for assessing E: "What expectations do you have of the company in terms of contributing towards the sustainability of the local economic system, e.g. hiring local employees or spending on locally based suppliers?” Employees were requested to answer using a five-point Likert scale: very low (1); low (2); fair (3); high (4); very high (5).

- Question for assessing P: "What perceptions do you have of the company in terms of contributing towards the sustainability of the local economic system, e.g. hiring local employees or spending on locally based suppliers?” Employees were requested to answer using the same five-point Likert scale. Similar pairs of questions were formulated for each CSR item: their content expresses the nature of the corresponding GRI indicators, as described in Table 2. The questionnaire was pre-tested on 10 bank employees in order to ensure clear understanding and to avoid any vagueness.

\subsection{Data selection, collection and analysis}

The 11 banks selected for inclusion in the current study are among Italy's largest in terms of stock capitalisation and quotation. The selection was also based on the fact that each of the 11 banks declares a commitment to CSR, as identified by the preparation of annual sustainability reports and the inclusion of "sustainability" sections on the company websites.

The content analysis of the CSR commitment disclosed by the banks was based on their sustainability reports and websites ${ }^{1}$, and was performed simultaneously to the questionnaire data collection (2013). To reliably evaluate the CSR items, the content analysis was conducted by four CSR experts (involved in CSR research and teaching over the last 10 years), and discrepancies between the coders were subject to discussion, reanalysis and reconciliation (Lombard et al., 2002). Through the content analysis, CSR items were assigned judgement values with an overall intercoder reliability of 92.8\%. Intercoder reliability was calculated by means of the Krippendorff's alpha and the ReCal3® tool (Freelon, 2010; Krippendorff, 2004).

Due to time and resource constraints, it was decided to limit the questionnaire data collection by means of a two-stage sampling procedure. In the first stage, the authors sampled randomly 11 bank

\footnotetext{
${ }^{1}$ Exclusively internal communication content was not available for the selected banks. We thus decided to conduct our analysis only on information available to the public through banks' sustainability reports and websites.
} 
branches (one for each of the 11 Italian banks under study) with at least 15 front-line employees with similar levels of function and responsibility. In the second stage, the authors sampled 15 front-line employees per branch. The sampling inside each branch was based, when available, on data regarding distribution by gender, age and educational level of the bank employees; otherwise, on distribution by gender, age and educational level of the national population (Italian National Institute of Statistics, 2013). In three cases out of 11 (Bank 7, Bank 6 and Bank 4), the authors could not get more than 9, 11 and 13 interviews per branch, respectively, due to employees' unavailability. The dataset for the analysis is thus composed of 153 employees from 11 banks. Table 3 provides the characteristics of the dataset and its coverage with respect to gender (female/male), age characteristics (under 35 years old; and over 35), and education (graduates/non-graduates). The distinction between employees under 35 years old (Generation Y, or simply “Gen Y”) (see also: Mang and Piper, 2013; and Solnet et al., 2012) and over 35 (nonGeneration Y) is motivated by the fact that only recently in Europe has there been a maturation of CSR as an academic field within business schools, both in terms of teaching and research (Matten and Moon, 2004; Orlitzky and Moon, 2011). Generation Y is also an age group that shows a deep sensitivity towards ethical and CSR issues (Cone Communications, 2016; Connell et al., 2012; Howe and Strauss, 2000), resulting in companies bearing such employees in mind when deciding on CSR practices (Klimkiewicz and Oltra, 2017). The authors thus assume that employees over 35 years old have been less exposed to CSR than younger employees throughout their education.

When submitting the questionnaires, participation was voluntary and anonymity was assured. Participants were informed prior that they would be answering questions regarding 41 CSR items.

The internal consistency of questionnaires submitted to employees was analysed using the Cronbach's alpha, which is at an acceptable level both for CSR expectations (E) and CSR perceptions (P), being 94.6\% and 95.3\%, respectively (Cronbach, 1972). Data were analysed by using IBM $\AA$ SPSS ${ }^{\circledR}$ Statistics version 24 (IBM Corporation, IBM Inc., Armonk, NY, USA).

Insert Table 3 about here 


\section{Results}

The aim of this section is to examine the statistical and substantive significance of gender, age and educational differences in employee demandingness, trust and satisfaction regarding CSR. In the first subsection, the general results are presented, followed by the results of gender, age, and educational level, and then by a summary of the results.

\subsection{General results}

In general, the analysis shows that employees are very demanding in terms of CSR commitment. They expect companies to deliver, on average, a higher level of commitment than the one that companies actually report (Table 4). Regarding trust in CSR, employees are found to be, on average, trustful of companies’ CSR commitment. Satisfaction in CSR fares less positively, however, with employees being dissatisfied with companies’ CSR efforts on the whole. Figure 2 shows the distributions of average levels of employee demandingness, trust and satisfaction regarding CSR (\%).

Insert Table 4 about here

Insert Figure 2 about here

\subsection{Results by gender}

Regarding demandingness of CSR, the analysis shows that employees' CSR expectations, on average, are not met by companies' CSR disclosure (Table 5). Student $t$-tests conducted in the analysis of gender differences show that, on average, men and women do not significantly differ in terms of CSR 
demandingness (Cohen's $d=0.040, p$-value $=0.402){ }^{2}$

Regarding trust in CSR, employees are found to be, on average, trustful of companies’ CSR commitment. In particular, the results show that, on average, men are slightly more trustful than women (Cohen's $d=-0.247, p$-value $=0.065)$.

Concerning satisfaction with CSR, employees' perceptions are, on average, lower than their expectations. Thus, employees are generally dissatisfied, with male employees generally less dissatisfied than their female counterparts (Cohen's $d=-0.349$, $p$-value $=0.017$ ).

Insert Table 5 about here

\subsection{Results by age}

Analysing age, Table 6 shows that employee demandingness of CSR does not seem to vary significantly when comparing answers obtained by employees under 35 years old (Gen $\mathrm{Y}$ ) and those over 35 (non-Gen Y) (Cohen’s $d=-0.098$, $p$-value = 0.292).

Furthermore, regarding trust in CSR, the analysis shows no significant age differences (Cohen's $d=$ 0.017, $p$-value $=0.461)$.

Finally, the analysis of satisfaction with CSR shows no significant differences between younger and older employees (Cohen's $d=0.137, p$-value $=0.461$ ).

Insert Table 6 about here

${ }^{2}$ Cohen's $d$ is one of the most commonly applied measurements for effect size and is defined as the difference between two means divided by a standard deviation for the data [1] (see Cohen, 1988). It is calculated as: $\left.d=\overline{(X}_{1}-\bar{X}_{2}\right) / s_{p}$ where $\bar{X}_{1}$ is the mean of the first group, $\bar{X}_{2}$ is the mean of the second group, and $s_{p}$ is the pooled standard deviation; a measure of the average within-group variation. $s_{p}$ is defined in [2] as:

$s_{p}=\sqrt{\frac{\left(n_{1}-1\right) s_{1}^{2}+\left(n_{2}-1\right) s_{2}^{2}}{n_{1}+n_{2}}}$

Where $s_{1}, s_{2}, n_{1}$, and $n_{2}$ are the standard deviations and sample sizes for the first and second group samples. Cohen (1988, p. 40) defined a Cohen's d of 0.2, 0.5, and 0.8 as small, medium and large effect sizes, respectively. 


\title{
4.4 Results by educational level
}

Analysing educational level, Table 7 shows that graduate employees are slightly more demanding than non-graduates (Cohen's $d=0.238, p$-value $=0.072$ ).

Regarding trust in CSR, graduates are found to be significantly more trustful of a company's CSR commitment than non-graduates (Cohen's $d=0.901$, $p$-value $<0.01$ ).

Analysis of satisfaction with CSR shows that employees are, on average, dissatisfied with their company's CSR efforts, regardless of their educational level. However, graduates are found to be significantly less dissatisfied than non-graduates (Cohen’s $d=0.762$, $p$-value $<0.01$ ).

\author{
Insert Table 7 about here
}

\subsection{Summary of results}

Table 8 shows the acceptance (or not) of study hypotheses on the differences in CSR attitudes for different employee gender, age and educational level groups.

Regarding gender differences, hypotheses $\mathrm{H}_{1 \mathrm{~b}}$ and $\mathrm{H}_{1 \mathrm{c}}$ are accepted (both with small substantive significance levels), while hypothesis $\mathrm{H}_{1 \mathrm{a}}$ is rejected. Thus, employee trust and satisfaction regarding CSR seem to slightly vary according to differences in gender, with male employees generally more trustful and satisfied than female colleagues. However, employee demandingness of CSR does not vary for female and male employees.

Concerning age differences, all the hypotheses $\left(\mathrm{H}_{2 a}, \mathrm{H}_{2 b}\right.$ and $\left.\mathrm{H}_{2 c}\right)$ are rejected: no significant age differences are observed in the demandingness, trust and satisfaction regarding CSR.

The analysis of educational level differences shows that all hypotheses $\left(\mathrm{H}_{3 a}, \mathrm{H}_{3 b}\right.$ and $\left.\mathrm{H}_{3 c}\right)$ are accepted, with small, large and medium substantive significance levels, respectively. Graduates are slightly more demanding, largely more trustful and generally more satisfied than non-graduates. 
Insert Table 8 about here

\section{Discussions}

The findings of this study suggest that employees are generally very demanding in terms of CSR efforts and that, although they are trustful of their company's commitment to sustainability, they are not completely satisfied with it.

Regarding gender differences, male employees are, on average, slightly more trustful in and satisfied with CSR performance than their female colleagues. These results are coherent with those obtained by Panwar et al. (2010), who find men to be more satisfied that their company is fulfilling their socioenvironmental responsibilities, and by Smith and Kumar (2013), who find men to be more affected by CSR initiatives. Gender differences in terms of demandingness of CSR are not significant, however.

In terms of age differences, the results of this study generally confirm the results of other studies (e.g. Eweje and Brunton, 2010; Gholipour et al., 2012; Laroche et al., 2001) in not finding significant and coherent evidence of age differences in CSR attitudes.

Regarding differences in educational level, the analysis shows that graduates are slightly more demanding, largely more trustful and generally more satisfied than non-graduates. These findings are in line with the results of Sobczak et al. (2006) and Quazi (2003), who show that educational level can determine attitudes and perceptions towards CSR. Conversely, these results do not confirm those obtained by Pérez and Rodríguez del Bosque (2013) and Akman (2011), who state that educational level does not have an influence on the formation process of CSR and business ethics perceptions.

This study shows that male and graduate employees are more trustful of and satisfied with CSR than females and non-graduates. Highly educated male employees are also more likely to advance their careers in Italy, and to become part of top management (Grant Thornton, 2017). In this context, employee similarity to their leaders and top managers (who are also most likely to be male graduates) can play an important role in employee attitudes towards CSR (Epitropaki and Martin, 1999; Green et al., 1996), and can positively influence employee trust and satisfaction regarding CSR. 


\section{Conclusions}

This study investigates the degree to which three employee CSR attitudes (demandingness of CSR, trust in CSR and satisfaction with CSR) vary according to gender, age, and educational level differences. The analysis was carried out by examining employee attitudes towards CSR in 11 Italian banks. The findings suggest that male employees are, on average, slightly more trustful in and satisfied with CSR performance than their female counterparts. Graduates are slightly more demanding, largely more trustful and generally more satisfied than non-graduates. However, the difference between older and younger employees is not significant.

From a theoretical perspective, this study contributes to the literature on CSR and employee attitudes by providing a framework with which to assess employees' attitudes towards CSR, and a method to investigate gender, age and educational level differences in CSR attitudes.

From a practical perspective, companies can be inspired by this analysis to investigate their own employees' attitudes towards CSR, identifying variations depending on employees' characteristics, designing tailored CSR programmes and activities, and implementing changes in terms of internal CSR communication (Amaladoss and Manohar, 2013; Sanchez-Hernandez and Grayson, 2012). In accordance with this perspective and within the context of the Italian banking sector, the results of this study indicate that banking companies lack effective CSR programmes and internal CSR communication avenues that are geared towards female and non-graduate employees, who show the lowest levels of trust in and satisfaction with CSR.

\section{Limitations and Further Research}

When interpreting the study results, a limitation that is particularly worth considering is the nonavailability of exclusively internal communication content, for this might have influenced employee perceptions. Indeed, although scholars tend to consider internal and external CSR communication as being inextricably linked to one another (e.g. Brunton et al., 2017), the authors of this study believe that 
the availability of such internal information would have strengthened the study results.

As with all empirical studies, the limited sample size drives the generalisability of the findings. Moreover, although the sampling frame could be similar to banking companies around the globe, it could be rather different from other company types, such as production and trade companies. Furthermore, the companies' top management was not contained in the sample of this study.

Thus, replication of this study with more companies operating in different industrial sectors and more employees with different levels of responsibility may provide robustness to these findings. In future studies, the authors believe it is of crucial importance to investigate other types of links between employee attitudes towards CSR and employee diversity. In particular, it might be interesting to study the influence of geographical, cultural and socioeconomic status differences. In this regard Atakan et al. (2008), Derry (1989), Simga-Mugan et al. (2005) and Tsalikis et al. (2002) argue that stakeholder attitudes towards CSR can change according to the socio-cultural context in which the studies are conducted. Such analyses may be also repeated over time, for different CSR dimensions and indicators, and thus provide useful information for decision-makers formulating sustainability and CSR policies and strategies.

\section{References}

Abel J, Ittermann P. 2003. Exploring the Boundaries of Co-determination. In The changing contours of German industrial relations, Weitbrecht H, Müller-Jentsch W (eds). Rainer Hampp Verlag: München/Mering, Germany: 103-118.

Agarwal B. 1992. The Gender and Environment Debate: Lessons from India. Feminist Studies 18(1): 119. DOI: $10.2307 / 3178217$.

Akman V. 2011. Empirical Look at the Factors Affecting Perception of Business Ethics in Turkey. Emerging Markets Journal 1(1): 1-11.

Alonso-Almeida M del M. 2013. Environmental management in tourism: students’ perceptions and managerial practice in restaurants from a gender perspective. Journal of Cleaner Production 60: 201-207. DOI: 10.1016/j.jclepro.2012.11.034.

Alonso-Almeida M del M, Fernández de Navarrete FC, Rodriguez-Pomeda J. 2015. Corporate social 
responsibility perception in business students as future managers: a multifactorial analysis. Business Ethics: A European Review 24(1): 1-17. DOI: 10.1111/beer.12060.

Amaladoss MX, Manohar HL. 2013. Communicating Corporate Social Responsibility - A Case of CSR Communication in Emerging Economies. Corporate Social Responsibility and Environmental Management 20(2): 65-80. DOI: 10.1002/csr.287.

Aouina Mejri C, Bhatli D. 2014. CSR: Consumer responses to the social quality of private labels. Journal of Retailing and Consumer Services 21(3): 357-363. DOI: 10.1016/j.jretconser.2013.08.001.

Arvidsson S, Carlén V. 2012. Environmental and Cost Analysis at Volvo Locistics Corporation Emballage. Chalmers University of Technology: Gothenburg, Sweden.

Atakan MGS, Burnaz S, Topcu YI. 2008. An Empirical Investigation of the Ethical Perceptions of Future Managers with a Special Emphasis on Gender - Turkish Case. Journal of Business Ethics 82(3): 573-586. DOI: 10.1007/s10551-007-9577-z.

Bauman CW, Skitka LJ. 2012. Corporate social responsibility as a source of employee satisfaction. Research in Organizational Behavior 32: 63-86. DOI: 10.1016/j.riob.2012.11.002.

Bhatnagar J. 2007. Talent management strategy of employee engagement in Indian ITES employees: key to retention. Employee Relations 29(6): 640-663. DOI: 10.1108/01425450710826122.

Bolton SC, Kim RC hee, O’Gorman KD. 2011. Corporate Social Responsibility as a Dynamic Internal Organizational Process: A Case Study. Journal of Business Ethics 101(1): 61-74. DOI: 10.1007/s10551-010-0709-5.

Bosch G, Knuth M. 2003. Recent Developments in the Labour Market. In The changing contours of German industrial relations, Weitbrecht H, Müller-Jentsch W (eds). Rainer Hampp Verlag: München/Mering, Germany: 137-156.

Bouten L, Everaert P, Van Liedekerke L, De Moor L, Christiaens J. 2011. Corporate social responsibility reporting: A comprehensive picture? Accounting Forum. Elsevier Ltd 35(3): 187-204. DOI: 10.1016/j.accfor.2011.06.007.

Brunton M, Eweje G, Taskin N. 2017. Communicating Corporate Social Responsibility to Internal Stakeholders: Walking the Walk or Just Talking the Talk? Business Strategy and the Environment 26(1): 31-48. DOI: 10.1002/bse.1889.

Burton BK, Hegarty WH. 1999. Some Determinants of Student Corporate Social Responsibility Orientation. Business \& Society 38(2): 188-205. DOI: 10.1177/000765039903800204. 
Calabrese A, Costa R, Rosati F. 2015. A feedback-based model for CSR assessment and materiality analysis. Accounting Forum 39(4): 312-327. DOI: 10.1016/j.accfor.2015.06.002.

Calabrese A, Costa R, Rosati F. 2016. Gender differences in customer expectations and perceptions of corporate social responsibility. Journal of Cleaner Production 116: 135-149. DOI: 10.1016/j.jclepro.2015.12.100.

Capriotti P, Moreno Á. 2007. Corporate citizenship and public relations: The importance and interactivity of social responsibility issues on corporate websites. Public Relations Review 33(1): 84-91. DOI: 10.1016/j.pubrev.2006.11.012.

Chan J, Pun N, Selden M. 2013. The politics of global production: Apple, Foxconn and China's new working class. New Technology, Work and Employment 28(2): 100-115. DOI: 10.1111/ntwe.12008.

Chauhan SP, Chauhan D. 2008. Human Obsolescence A Wake-up Call to Avert a Crisis. Global Business Review 9(1): 85-100.

Cho JE, Hu H. 2009. The effect of service quality on trust and commitment varying across generations. International Journal of Consumer Studies 33(4): 468-476. DOI: 10.1111/j.14706431.2009.00777.x.

Cohen J. 1988. Statistical power analysis for the behavioral sciences. Lawrence Erlbaum Associates: Hillsdale, NJ, 2nd.

Cone Communications. 2016. 2015 Cone Communications Millennial CSR Study. Available at: http://www.conecomm.com/research-blog/2015-cone-communications-millennial-csr-study.

Connell JA, McMinn NE, Bell N. 2012. How will the Next Generation Change the Business World? A Report on a Survey. Insights to a Changing World Journal 2012(4): 100-114.

Coutinho V et al. 2017. Employee-Driven Sustainability Performance Assessment in Public Organisations. Corporate Social Responsibility and Environmental Management. DOI: 10.1002/csr.1438.

Cronbach LJ. 1972. The dependability of behavioral measurements: Theory of generalizability for scores and profiles. John Wiley \& Sons: New York (NY).

Dangelico RM. 2015. Improving Firm Environmental Performance and Reputation: The Role of Employee Green Teams. Business Strategy and the Environment 24(8): 735-749. DOI: 10.1002/bse.1842.

Dellaportas S. 2006. Making a difference with a discrete course on accounting ethics. Journal of Business 
Ethics 65(4): 391-404. DOI: 10.1007/s10551-006-0020-7.

Derry R. 1989. An empirical study of moral reasoning among managers. Journal of Business Ethics 8(11): 855-862. DOI: 10.1007/BF00384528.

Dirks KT, Ferrin DL. 2001. The role of trust in organizational settings. Organization Science 12(4): 450467. DOI: $10.1287 /$ orsc.12.4.450.10640.

Du S, Bhattacharya CB, Sen S. 2010. Maximizing Business Returns to Corporate Social Responsibility (CSR): The Role of CSR Communication. International Journal of Management Reviews 12(1): 819. Available at: http://doi.wiley.com/10.1111/j.1468-2370.2009.00276.x.

Elias RZ. 2004. An Examination of Business Students' Perception of Corporate Social Responsibilities Before and After Bankruptcies. Journal of Business Ethics 52(3): 267-281. DOI: 10.1023/B:BUSI.0000037558.74693.d5.

Epitropaki O, Martin R. 1999. The impact of relational demography on the quality of leader-member exchanges and employees' work attitudes and well-being. Journal of Occupational and Organizational Psychology 72(2): 237-240. DOI: 10.1348/096317999166635.

European Commission. 2011. A renewed EU strategy 2011-14 for Corporate Social Responsibility. Bruxelles, Belgium. DOI: 10.1017/CBO9781107415324.004.

Eweje G, Brunton M. 2010. Ethical perceptions of business students in a New Zealand university: Do gender, age and work experience matter? Business Ethics 19(1): 95-111. DOI: 10.1111/j.14678608.2009.01581.x.

Farneti F, Guthrie J. 2009. Sustainability reporting by Australian public sector organisations: Why they report. Accounting Forum 33(2): 89-98. DOI: 10.1016/j.accfor.2009.04.002.

Farrell MA. 2003. The effect of downsizing on market orientation: the mediating roles of trust and commitment. Journal of Strategic Marketing 11(1): 55-74. DOI: 10.1080/0965254032000069748.

Fernandez-Feijoo B, Romero S, Ruiz-Blanco S. 2014a. Women on boards: Do they affect sustainability reporting? Corporate Social Responsibility and Environmental Management 21(6): 351-364. DOI: 10.1002/csr.1329.

Fernandez-Feijoo B, Romero S, Ruiz S. 2014b. Effect of Stakeholders' Pressure on Transparency of Sustainability Reports within the GRI Framework. Journal of Business Ethics 122(1): 53-63. DOI: 10.1007/s10551-013-1748-5.

Fisher CD, Locke EA. 1992. The new look in job satisfaction research and theory. In Job Satisfaction: 
How People Feel about their Jobs and How it Affects their Performance, Smith PC, Cranny CJ, Stone EF (eds). Lexington Books: New York (NY).

Freelon DG. 2010. ReCal: Intercoder Reliability Calculation as a Web Service. International Journal of Internet Science 5(1): 20-33.

Gabbatt A. 2012, October 5. Foxconn workers on iPhone 5 line strike in China, rights group says. The Guardian.

Gholipour TH, Nayeri MD, Mehdi S, Mehdi M. 2012. Investigation of attitudes about corporate social responsibility: Business students in Iran. African Journal of Business Management 6(14): 51055113. DOI: 10.5897/AJBM11.2699.

Global Reporting Initiative. 2011. G3.1 Sustainability Reporting Guidelines. Global Reporting Initiative. Available at: https://www.globalreporting.org/resourcelibrary/G3.1-Guidelines-Incl-TechnicalProtocol.pdf.

González-Benito J, González-Benito Ó. 2010. A study of determinant factors of stakeholder environmental pressure perceived by industrial companies. Business Strategy and the Environment 19(3): 164-181. DOI: 10.1002/bse.631.

Grant Thornton. 2017. Women in senior roles and new perspectives on risk. Available at: http://www.bgt-grantthornton.it/en/insights/articles/women-in-business-2017/ [10 July 2017].

Green SG, Anderson SE, Shivers SL. 1996. Demographic and Organizational Influences on LeaderMember Exchange and Related Work Attitudes. Organizational Behavior and Human Decision Processes 66(2): 203-214. DOI: 10.1006/obhd.1996.0049.

Gupta AK, Raj SP, Wilemon D. 1986. A model for studying R\&D-marketing interface in the product innovation process. Journal of Marketing 50(2): 7-17. Available at: http://search.ebscohost.com/login.aspx?direct=true\&db=bth\&AN=4999838\&site=ehost-live.

Guthrie J, Abeysekera I. 2006. Content analysis of social, environmental reporting: what is new? Journal of Human Resource Costing \& Accounting 10(2): 114-126. DOI: 10.1108/14013380610703120.

Hansen SD, Dunford BB, Boss AD, Boss RW, Angermeier I. 2011. Corporate Social Responsibility and the Benefits of Employee Trust: A Cross-Disciplinary Perspective. Journal of Business Ethics 102(1): 29-45. DOI: 10.1007/s10551-011-0903-0.

Hemdi MA, Nasurdin AM. 2007. Investigating the Influence of Organizational Justice on Hotel Employees’ Organizational Citizenship Behavior Intentions and Turnover Intentions. Journal of 
Human Resources in Hospitality \& Tourism 7(1): 1-23. DOI: 10.1300/J171v07n01_01.

Hemingway CA, Maclagan PW. 2004. Managers’ personal values as drivers of corporate social responsibility. Journal of Business Ethics 50(1): 33-44. DOI: 10.1023/B:BUSI.0000020964.80208.c9.

ter Hoeven CL, Verhoeven JWM. 2013. 'Sharing is caring' Corporate social responsibility awareness explaining the relationship of information flow with affective commitment. Corporate Communications: An International Journal 18(2): 264-279. DOI: 10.1108/13563281311319526.

Howe N, Strauss W. 2000. Millennials Rising: The Next Great Generation. Vintage Books. DOI: 10.1108/jcm.2002.19.3.282.4.

Italian National Institute of Statistics. 2013. Popolazione Residente. Available at: http://demo.istat.it/pop2013/index.html [30 January 2018].

Jizi M. 2017. The influence of board composition on sustainable development disclosure. Business Strategy and the Environment 26: 640-655. DOI: 10.1002/bse.1943.

Judge TA, Thoresen CJ, Bono JE, Patton GK. 2001. The Job Satisfaction-Job Performance Relationship: A Qualitative and Quantitative Review. Psychological Bulletin 127(3): 376-407. DOI: 10.1037/0033-2909.127.3.376.

Kelley SW, Donnelly JH, Skinner SJ. 1990. Customer participation in service production and delivery. Journal of Retailing 63: 315-335.

Kidwell JM, Stevens RE, Bethke AL. 1987. Differences in ethical perceptions between male and female managers: Myth or reality? Journal of Business Ethics 6(6): 489-493.

Klimkiewicz K, Oltra V. 2017. Does CSR Enhance Employer Attractiveness? The Role of Millennial Job Seekers’ Attitudes. Corporate Social Responsibility and Environmental Management. DOI: 10.1002/csr.1419.

Koh H, Boo E. 2004. Organisational ethics and employee satisfaction and commitment. Management Decision 42(5): 677-693. DOI: 10.1108/00251740410538514.

Kolk A, Pinkse J. 2010. The integration of corporate governance in corporate social responsibility disclosures. Corporate Social Responsibility and Environmental Management 17(1): 15-26. DOI: 10.1002/csr.196.

Kramer JK, Vasconcellos GM. 1996. The Economic Effect of Strikes on the Shareholders of Nonstruck Competitors. Industrial and Labor Relations Review 49(2): 213-222. 
Krippendorff K. 2004. Content Analysis: An Introduction to its Methodology. Sage Publications: Thousand Oaks (CA).

Lamberton G. 2005. Sustainability accounting-a brief history and conceptual framework. Accounting Forum 29(1): 7-26. DOI: 10.1016/j.accfor.2004.11.001.

Lämsä A-M, Vehkaperä M, Puttonen T, Pesonen H-L. 2008. Effect of Business Education on Women and Men Students’ Attitudes on Corporate Responsibility in Society. Journal of Business Ethics 82(1): 45-58. DOI: 10.1007/s10551-007-9561-7.

Laroche M, Bergeron J, Barbaro-Forleo G. 2001. Targeting consumers who are willing to pay more for environmentally friendly products. Journal of Consumer Marketing 18(6): 503-520. DOI: 10.1108/EUM0000000006155.

Law MMS, Hills P, Hau BCH. 2017. Engaging Employees in Sustainable Development - a Case Study of Environmental Education and Awareness Training in Hong Kong. Business Strategy and the Environment 26(1): 84-97. DOI: 10.1002/bse.1903.

Lawal E, May G, Stahl B. 2017. The Significance of Corporate Social Disclosure for High-Tech Manufacturing Companies: Focus on Employee and Community Aspects of Sustainable Development. Corporate Social Responsibility and Environmental Management 24(4): 295-311. Available at: http://doi.wiley.com/10.1002/csr.1397.

Li T, Calantone RJ. 1998. The Impact of Market Knowledge Competence on New Product Advantage: Conceptualization and Empirical Examination. Journal of Marketing 62(4): 13. Available at: http://www.jstor.org/stable/1252284?origin=crossref.

Lombard M, Snyder-Duch J, Bracken CC. 2002. Content Analysis in Mass Communication: Assessment and Reporting of Intercoder Reliability. Human Communication Research 28(4): 587-604. DOI: 10.1093/hcr/28.4.587.

Luthar HK, DiBattista RA, Gautschi T. 1997. Perception of What the Ethical Climate is and What it Should be: The Role of Gender, Academic Status, and Ethical Education. Journal of Business Ethics 16(2): 205-217.

Mang CF, Piper LA. 2013. Perceptions of a Triple Bottom Line Approach to Doing Business among Generation Y Canadians 3(1): 26-40.

Martinuzzi A, Gisch-Boie S, Wiman A. 2010. Does Corporate Responsibility Pay Off? Exploring the links between CSR and competitiveness in Europe's industrial sectors. Scientific series of the 
Research Institute for Managing Sustainability. Vienna University of Economics and Business, Vienna, Austria.

Marz JW, Powers TL, Queisser T. 2003. Corporate and Individual Influences on Managers’ Social Orientation. Journal of Business Ethics 46(1): 1-11.

Matten D, Moon J. 2004. Corporate social responsibility education in Europe. Journal of Business Ethics 54(4): 323-337. DOI: 10.1007/s10551-004-1822-0.

Michailides TP, Lipsett MG. 2013. Surveying employee attitudes on corporate social responsibility at the frontline level of an energy transportation company. Corporate Social Responsibility and Environmental Management 20(5): 296-320. DOI: 10.1002/csr.1291.

Morgan RM, Hunt SD. 1994. The Commitment-Trust Theory of Relationship Marketing. Journal of Marketing 58(3): 20-38. DOI: 10.1177/1356766710391135.

Morris MG, Venkatesh V. 2000. Age differences in technology adoption decisions: Implications for a changing work force. Personnel Psychology 53(2): 375-403. DOI: 10.1111/j.1744-6570.2000.tb00206.x.

Neuendorf KA. 2002. The Content Analysis Guidebook. Sage Publications: Thousand Oaks (CA).

Onkila T. 2015. Pride or Embarrassment? Employees’ Emotions and Corporate Social Responsibility. Corporate Social Responsibility and Environmental Management 22(4): 222-236. Available at: http://doi.wiley.com/10.1002/csr.1340.

Orlitzky M, Moon J. 2011. Assessing Corporate Social Responsibility in Europe. In Toward Assessing Business Ethics Education, Swanson DL, Fisher DG (eds). Information Age Publishing: Charlotte (NC): 143-176.

Pakdil F, Harwood TN. 2005. Patient satisfaction in a preoperative assessment clinic: An analysis using SERVQUAL dimensions. Total Quality Management and Business Excellence 16(1): 15-30. DOI: 10.1080/1478336042000255622.

Panwar R, Hansen E, Anderson R. 2010. Students’ perceptions regarding CSR success of the US forest products industry. Social Responsibility Journal 6(1): 18-32. DOI: 10.1108/17471111011024522.

Parasuraman A, Zeithaml VA, Berry LL. 1988. SERVQUAL: A Multiple-Item Scale for Measuring Consumer Perceptions of Service Quality. Journal of Retailing 64(1): 12-40. DOI: 10.1016/S01482963(99)00084-3.

Pérez A, Rodríguez del Bosque I. 2013. Customer personal features as determinants of the formation 
process of corporate social responsibility perceptions. Psychology and Marketing 30(10): 903-917. DOI: 10.1002/mar.20654.

Perkins PE. 2007. Feminist ecological economics and sustainability. Journal of Bioeconomics 9(3): 227244. DOI: 10.1007/s10818-007-9028-z.

Perrini F. 2005. Building a European portrait of corporate social responsibility reporting. European Management Journal 23(6): 611-627. DOI: 10.1016/j.emj.2005.10.008.

Perryer C, Jordan C. 2002. The Influence of Gender, Age, Culture and other Factors on Ethical Beliefs: A Comparative Study in Australia and Singapore. Public Administration \& Management: An Interactive Journal 7(4): 367-382.

Piper L, Mang C, Knox J, Waddell C. 2012. Student perceptions toward a triple bottom line approach. Journal of Academic and Business Ethics 6: 1-18.

Pollach I. 2003. Communicating Corporate Ethics on the World Wide Web: A Discourse Analysis of Selected Company Web Sites. Business \& Society 42(2): 277-287. DOI: 10.1177/0007650303042002006.

Prasad JN, Marlow N, Hattwick RE. 1998. Gender-Based Differences in Perception of a Just Society. Journal of Business Ethics 17(3): 219-228. DOI: 10.1023/A:1017968526608.

Probst G, Raisch S. 2005. Organizational crisis: The logic of failure. Academy of Management Perspectives 19(1): 90-105. DOI: 10.5465/AME.2005.15841958.

Quazi AM. 2003. Identifying the determinants of corporate managers' perceived social obligations. Management Decision 41(9): 822-831. DOI: 10.1108/00251740310488999.

Ruegger D, King EW. 1992. A study of the effect of age and gender upon student business ethics. Journal of Business Ethics 11(3): 179-186. DOI: 10.1007/BF00871965.

Sanchez-Hernandez I, Grayson D. 2012. Internal marketing for engaging employees on the corporate responsibility journey. Intangible Capital 8(2): 275-307. DOI: 10.3926/ic.305.

Seele P, Lock I. 2015. Instrumental and/or Deliberative? A Typology of CSR Communication Tools. Journal of Business Ethics. Springer Netherlands 131(2): 401-414. Available at: http://dx.doi.org/10.1007/s10551-014-2282-9.

Shiva V. 1988. Staying Alive: Women, Ecology and Development. Zed Books Ltd: London (UK). Simga-Mugan C, Daly BA, Onkal D, Kavut L. 2005. The influence of nationality and gender on ethical sensitivity: An application of the issue-contingent model. Journal of Business Ethics 57(2): 139- 
159. DOI: 10.1007/s10551-004-4601-z.

Singhapakdi A, Lee DJ, Sirgy MJ, Senasu K. 2015. The impact of incongruity between an organization's CSR orientation and its employees' CSR orientation on employees' quality of work life. Journal of Business Research 68(1): 60-66. DOI: 10.1016/j.jbusres.2014.05.007.

Smith S, Kumar A. 2013. Impact of corporate social responsibility on employee organizational commitment within the gaming industry. Advances in Hospitality and Leisure. Emerald Group Publishing Limited 9: 49-67. DOI: 10.1108/S1745-3542(2013)0000009007.

Sobczak A, Debucquet G, Havard C. 2006. The impact of higher education on students' and young managers' perception of companies and CSR: an exploratory analysis. Corporate Governance 6(1): 463-474. DOI: 10.1108/14720700610689577.

Solnet D, Kralj A, Kandampully J. 2012. Generation Y employees: An examination of work attitude differences. Journal of Applied Management and Entrepreneurship 17(3): 36-54.

Tsalikis J, Seaton B, Tomaras P. 2002. A New Perspective on Cross-Cultural Ethical Evaluations: The Use of Conjoint Analysis. Journal of Business Ethics 35(4): 281-292.

Tzafrir SS, More K V. 2006. Trust as a mediator between organizational justice and work behaviors in a cross-cultural context. Academy of Management Proceedings 8(1): E1-E6. DOI: 10.5465/AMBPP.2006.27162875.

Veuthey S, Gerber J-F. 2010. Logging conflicts in Southern Cameroon: A feminist ecological economics perspective. Ecological Economics 70(2): 170-177. DOI: 10.1016/j.ecolecon.2009.09.012.

Vlachos PA, Panagopoulos NG, Rapp AA. 2013. Feeling Good by Doing Good: Employee CSR-Induced Attributions, Job Satisfaction, and the Role of Charismatic Leadership. Journal of Business Ethics 118(3): 577-588. DOI: 10.1007/s10551-012-1590-1.

Wang G, Netemeyer RG. 2002. The effects of job autonomy, customer demandingness, and trait competitiveness on salesperson learning, self-efficacy, and performance. Journal of the Academy of Marketing Science 30(3): 217-228. DOI: 10.1177/00970302030003003.

Weber RP. 1990. Basic content analysis. Sage Publications: Thousand Oaks (CA).

Wheelwright SC, Clark KB. 1992. Revolutionizing Product Development: Quantum Leaps in Speed, Efficiency, and Quality. The Free Press: New York (NY).

Yu M. 2009. Employees' perception of organizational change: the mediating effects of stress management strategies. Public Personnel Management 38(1): 17-33. DOI: 
10.1177/009102600903800102.

Zemke R. 2000. Can you manage trust? Training 37(2): 76-81.

Zhu Q, Hang Y, Liu J, Lai K hung. 2014. How is employee perception of organizational efforts in corporate social responsibility related to their satisfaction and loyalty towards developing harmonious society in Chinese enterprises? Corporate Social Responsibility and Environmental Management 21(1): 28-40. DOI: 10.1002/csr.1302. 
Tables

\begin{tabular}{cl|ccc}
\hline \multirow{2}{*}{ Hypotheses } & \multicolumn{3}{c}{ CSR attitudes } \\
& a. Demandingness & b. Trust & c. Satisfaction \\
\hline \multirow{2}{*}{ Individual } & 1. Gender & $\mathrm{H}_{1 \mathrm{a}}$ & $\mathrm{H}_{1 \mathrm{~b}}$ & $\mathrm{H}_{1 \mathrm{c}}$ \\
characteristics & 2. Age & $\mathrm{H}_{2 \mathrm{a}}$ & $\mathrm{H}_{2 \mathrm{~b}}$ & $\mathrm{H}_{2 \mathrm{c}}$ \\
& 3. Educational level & $\mathrm{H}_{3 \mathrm{a}}$ & $\mathrm{H}_{3 \mathrm{~b}}$ & $\mathrm{H}_{3 \mathrm{c}}$ \\
\hline
\end{tabular}

Table 1: Study hypotheses. 


\begin{tabular}{|c|c|c|c|c|}
\hline \begin{tabular}{l|l} 
CSR \\
dimensions
\end{tabular} & $\begin{array}{l}\text { CSR sub- } \\
\text { dimensions }\end{array}$ & CSR items & GRI indicators & Brief description of CSR items and content of questions \\
\hline \multirow{6}{*}{ 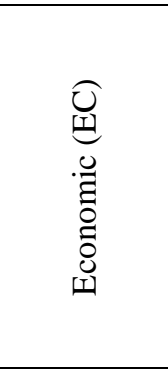 } & \multirow[t]{6}{*}{ 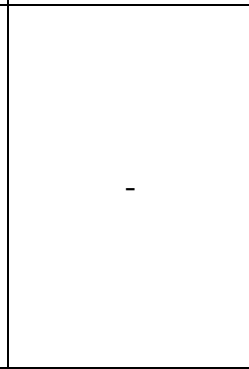 } & Direct economic value & EC1 & $\begin{array}{l}\text { Direct economic value generated and distributed by the organisation, e.g. employee compensation, } \\
\text { donations and other community investments. }\end{array}$ \\
\hline & & Climate change & EC2 & Risks and opportunities for the organisation's activities posed by climate change. \\
\hline & & Benefit plan obligations & EC3 & Coverage of the organisation's defined benefit plan obligations. \\
\hline & & $\begin{array}{l}\text { Financial assistance received } \\
\text { from governments }\end{array}$ & EC4 & Significant direct or indirect financial benefits received by the organisation from governments. \\
\hline & & Market presence & EC5 - EC7 & $\begin{array}{l}\text { Organisation's contribution to the sustainability of the local economic system, e.g. hiring local employees } \\
\text { and spending on locally based suppliers. }\end{array}$ \\
\hline & & Indirect Economic Impacts & EC8, EC9 & $\begin{array}{l}\text { Indirect economic impacts of the organisation's activities on the local economic system, e.g. investments } \\
\text { in public infrastructure and services. }\end{array}$ \\
\hline \multirow{11}{*}{ 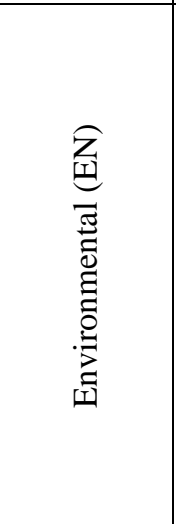 } & \multirow{11}{*}{ - } & Materials & EN1, EN2 & Efforts to reduce the material intensity and ability to use recycled input materials. \\
\hline & & Energy & EN3 - EN7 & Initiatives to reduce energy consumption. \\
\hline & & Water & EN8 - EN10 & Initiatives to reduce water consumption. \\
\hline & & Biodiversity & EN11 - EN15 & $\begin{array}{l}\text { Management of impacts on biodiversity, i.e. environmental protection and conservation of protected } \\
\text { areas, and areas of high biodiversity outside protected areas. }\end{array}$ \\
\hline & & Emissions & EN16 - EN20 & Initiatives to reduce emissions. \\
\hline & & Effluents & $\begin{array}{l}\text { EN21, EN23, } \\
\text { EN25 }\end{array}$ & Initiatives to reduce water discharge and spills of hazardous substances. \\
\hline & & Waste & EN22, EN24 & Initiatives to reduce waste and to improve hazardous waste management. \\
\hline & & Products and services & EN26, EN27 & Initiatives to mitigate environmental impacts of products and services. \\
\hline & & Compliance & EN28 & Compliance with environmental laws and regulations. \\
\hline & & Transport & EN29 & $\begin{array}{l}\text { Initiatives to reduce environmental impacts of transporting products and other materials used for the } \\
\text { organisation's operations, and transporting members of the workforce. }\end{array}$ \\
\hline & & Overall & EN30 & Expenditures for environmental protection. \\
\hline \multirow{14}{*}{ 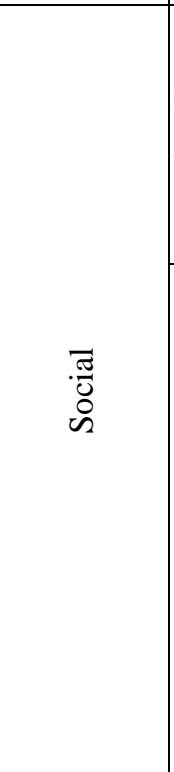 } & \multirow{5}{*}{$\begin{array}{l}\text { Labour Practices } \\
\text { and Decent } \\
\text { Work (LA) }\end{array}$} & Employment & LA1 - LA3 & Job stability and equity by gender, age, group and region. \\
\hline & & Labour/Management Relations & LA4, LA5 & Consultation with workers and other relevant parties. \\
\hline & & Occupational Health and Safety & LA6 - LA9 & $\begin{array}{l}\text { Management of occupational health and safety in the workplace, i.e. health and safety training, } \\
\text { counselling, prevention, risk-control programmes and committees. }\end{array}$ \\
\hline & & Training and Education & LA10 - LA12 & Training and assistance programmes to upgrade employee skills. \\
\hline & & Diversity and Equal Opportunity & LA13, LA14 & $\begin{array}{l}\text { Equal opportunity in salary and in the composition of workforce and governance bodies (according to } \\
\text { gender, age, race, etc.). }\end{array}$ \\
\hline & \multirow{9}{*}{$\begin{array}{l}\text { Human Rights } \\
\text { (HR) }\end{array}$} & $\begin{array}{l}\text { Investment and Procurement } \\
\text { Practices }\end{array}$ & HR1 - HR3 & $\begin{array}{l}\text { The organisation's integration of human rights into its external business relationships through either } \\
\text { investments or suppliers, contractors, and other business partners. }\end{array}$ \\
\hline & & \begin{tabular}{|l|} 
Non-discrimination \\
\end{tabular} & HR4 & Non-discrimination on grounds of race, gender, religion, political opinion, nationality, or social origin. \\
\hline & & $\begin{array}{l}\text { Freedom of Association and } \\
\text { Collective Bargaining }\end{array}$ & HR5 & $\begin{array}{l}\text { Protection of the right of workers (and employers) to organise collectively in organisations of their own } \\
\text { choice. }\end{array}$ \\
\hline & & Child Labour & HR6 & Measures taken to contribute to the effective abolition of child labour. \\
\hline & & Forced and Compulsory Labour & HR7 & Measures taken to contribute to the effective abolition of forced or compulsory labour. \\
\hline & & Security Practices & HR8 & $\begin{array}{l}\text { Efforts in training security personnel about the organisation's policies or procedures concerning aspects of } \\
\text { human rights that are relevant to operations. }\end{array}$ \\
\hline & & $\begin{array}{l}\text { Indigenous Rights and local } \\
\text { communities }\end{array}$ & HR9 & Respect of the indigenous and local communities rights. \\
\hline & & Assessment & HR10 & $\begin{array}{l}\text { Organisation's efforts in considering human rights when making decisions on its locations of operations, } \\
\text { e.g. number of operations that have been subject to human rights reviews and/or impact assessments. }\end{array}$ \\
\hline & & Remediation & HR11 & Efforts in addressing and solving human rights grievances. \\
\hline
\end{tabular}




\begin{tabular}{|c|c|c|c|}
\hline \multirow{5}{*}{ Society (SO) } & Local Communities & SO1, SO9, SO10 & $\begin{array}{l}\text { Management of impacts on local community, i.e. local community engagement, impact assessments, and } \\
\text { development programmes. }\end{array}$ \\
\hline & Corruption & $\mathrm{SO} 2-\mathrm{SO} 4$ & $\begin{array}{l}\text { Existence of supporting procedures and employee training to manage reputational risks arising from } \\
\text { corruption. }\end{array}$ \\
\hline & Public Policy & SO5, SO6 & $\begin{array}{l}\text { Extent to which publicly-expressed positions on sustainability are consistently embedded across the } \\
\text { organisation. }\end{array}$ \\
\hline & Anti-Competitive Behaviour & SO7 & $\begin{array}{l}\text { Actions that may result in collusion with potential competitors with the purpose of limiting the effects of } \\
\text { market competition. }\end{array}$ \\
\hline & Compliance & SO8 & $\begin{array}{l}\text { Compliance with laws and regulations related to accounting fraud, workplace discrimination and } \\
\text { corruption. }\end{array}$ \\
\hline \multirow{5}{*}{$\begin{array}{l}\text { Product } \\
\text { Responsibility } \\
\text { (PR) }\end{array}$} & Customer Health and Safety & PR1, PR2 & Systematic efforts to address health and safety across the life cycle of a product and/or service. \\
\hline & Product and Service Labelling & PR3 - PR5 & Accessible and adequate information and labelling on the sustainability impacts of products and services. \\
\hline & Marketing Communications & PR6, PR7 & $\begin{array}{l}\text { Marketing communications practices conforming to generally accepted ethical standards and privacy } \\
\text { regulations. }\end{array}$ \\
\hline & Customer Privacy & PR8 & Existence of management systems and procedures to ensure customer privacy protection. \\
\hline & Compliance & PR9 & Compliance with laws and regulations concerning provision and use of product and services. \\
\hline
\end{tabular}

Table 2: CSR dimensions, sub-dimensions and items considered in the study (adapted from Global Reporting Initiative, 2011). 


\begin{tabular}{cccccccr}
\hline & \multicolumn{2}{c}{ Gender } & \multicolumn{2}{c}{ Age } & \multicolumn{2}{c}{ Education } & \multirow{2}{*}{ Total } \\
\cline { 2 - 6 } & Female & Male & $<=35($ Gen Y) & $>35$ (Non-Gen Y) & Graduates & Non-graduates & \\
\hline N & $69(45.1)$ & $84(54.9)$ & $44(28.8)$ & $109(71.2)$ & $77(50.3)$ & $76(49.7)$ & 153 \\
\hline
\end{tabular}

Table 3: Sample characteristics (\% with respect to all surveyed employees in parentheses). 


\begin{tabular}{cccc}
\hline & $\begin{array}{c}\text { CSR Demandingness } \\
(\mathrm{E}-\mathrm{D})\end{array}$ & $\begin{array}{c}\text { CSR Trust } \\
(\mathrm{P}-\mathrm{D})\end{array}$ & $\begin{array}{c}\text { CSR Satisfaction } \\
(\mathrm{P}-\mathrm{E})\end{array}$ \\
\hline Average & 1.30 & 0.52 & -0.77 \\
\hline Median & 1.41 & 0.56 & -0.66 \\
\hline Standard Deviation & 0.77 & 0.79 & 0.66 \\
\hline Max & 2.93 & 1.98 & 0.34 \\
\hline Min & -0.98 & -1.12 & -2.80 \\
\hline \% of employees with a positive CS attitude & 96.1 & 71.9 & 14.4 \\
\hline Table 4: Descriptive statistics for employees' CSR demandingness, trust and satisfaction.
\end{tabular}

Table 4: Descriptive statistics for employees' CSR demandingness, trust and satisfaction. 


\begin{tabular}{cllccccc}
\hline CSR attitude & Gender & $N$ & Mean & Std. deviation & Std. error mean & $t$-test p & Cohen’s $d$ \\
\hline Demandingness & Female & 69 & 1.31 & 0.721 & 0.087 & 0.402 & 0.040 \\
(E-D) & Male & 84 & 1.28 & 0.821 & 0.090 & & \\
\hline Trust & Female & 69 & 0.42 & 0.816 & 0.098 & 0.065 & -0.247 \\
(P-D) & Male & 84 & 0.61 & 0.767 & 0.084 & $*$ & $\circ$ \\
\hline Satisfaction & Female & 69 & -0.90 & 0.655 & 0.079 & 0.017 & -0.349 \\
(P-E) & Male & 84 & -0.67 & 0.645 & 0.070 & $* *$ & $\circ$ \\
\hline
\end{tabular}

Table 5: Gender differences in CSR attitudes.

Statistical significance: ${ }^{*}$-value $<0.10,{ }^{* *}$-value $<0.05,{ }^{* * *} p$-value $<0.01$.

Substantive significance: ${ }^{\circ}$ Cohen's $d>|0.20|,{ }^{\circ}$ Cohen's $d>|0.50|,{ }^{\circ}$ Cohen's $d>|0.80|$. 


\begin{tabular}{clcccccc}
\hline CSR attitude & \multicolumn{1}{c}{ Age } & $N$ & Mean & Std. deviation & Std. error mean & $t$-test p & Cohen’s $d$ \\
\hline Demandingness & $<=35$ (Gen Y) & 44 & 1.24 & 0.699 & 0.105 & 0.292 & -0.098 \\
$($ E-D) & $>35$ (non-Gen Y) & 109 & 1.32 & 0.806 & 0.077 & & \\
\hline Trust & $<=35($ Gen Y) & 44 & 0.53 & 0.760 & 0.115 & 0.461 & 0.017 \\
$($ P-D) & $>35$ (non-Gen Y) & 109 & 0.52 & 0.809 & 0.078 & & \\
\hline Satisfaction & $<=35($ Gen Y) & 44 & -0.71 & 0.523 & 0.079 & 0.223 & 0.137 \\
$(\mathrm{P}-\mathrm{E})$ & $>35$ (non-Gen Y) & 109 & -0.80 & 0.704 & 0.067 & & \\
\hline
\end{tabular}

Table 6: Age differences in CSR attitudes.

Statistical significance: ${ }^{*}$-value $<0.10,{ }^{* *}$-value $<0.05,{ }^{* * *} p$-value $<0.01$.

Substantive significance: ${ }^{\circ}$ Cohen's $d>|0.20|,{ }^{\circ}$ Cohen's $d>|0.50|,{ }^{\circ \circ}$ Cohen's $d>|0.80|$. 


\begin{tabular}{clcccccc}
\hline CSR attitude & Educational level & $N$ & Mean & Std. deviation & Std. error mean & $t$-test p & Cohen’s $d$ \\
\hline Demandingness & Graduates & 77 & 1.39 & 0.759 & 0.086 & 0.072 & 0.238 \\
$($ E-D) & Non-graduates & 76 & 1.20 & 0.785 & 0.090 & $*$ & $\circ$ \\
\hline Trust & Graduates & 77 & 0.85 & 0.749 & 0.085 & 0.000 & 0.901 \\
$(\mathrm{P}-\mathrm{D})$ & Non-graduates & 76 & 0.20 & 0.698 & 0.080 & $* * *$ & $\circ$ \\
\hline Satisfaction & Graduates & 77 & -0.54 & 0.558 & 0.064 & 0.000 & 0.762 \\
$(\mathrm{P}-\mathrm{E})$ & Non-graduates & 76 & -1.01 & 0.668 & 0.077 & $* * *$ & $\circ$ \\
\hline
\end{tabular}

Table 7: Educational-level differences in CSR attitudes.

Statistical significance: ${ }^{*} p$-value $<0.10,{ }^{* *} p$-value $<0.05,{ }^{* * *} p$-value $<0.01$.

Substantive significance: ${ }^{\circ}$ Cohen's $d>|0.20|,{ }^{\circ}$ Cohen's $d>|0.50|,{ }^{\circ}$ Cohen's $d>|0.80|$. 


\begin{tabular}{cl|ccc}
\hline \multirow{2}{*}{ Hypotheses } & \multicolumn{3}{c}{ CSR attitudes } \\
& a. Demandingness & b. Trust & c. Satisfaction \\
\hline Individual & $\begin{array}{l}\text { 1. Gender } \\
\text { 2. Age } \\
\text { characteristics }\end{array}$ & & ${ }^{\circ}(*)$ & ${ }^{\circ}(* *)$ \\
& 3. Educational level & ${ }^{\circ}(*)$ & $\circ \circ(* * *)$ & $\circ(* * *)$ \\
\hline
\end{tabular}

Table 8: Study hypotheses and levels of substantive significance of gender, age, and educational differences (levels of statistical significance in parentheses).

Substantive significance: ${ }^{\circ}$ Cohen's $d>|0.20|,{ }^{\circ}$ Cohen's $d>|0.50|,{ }^{\circ 0 \circ}$ Cohen's $d>|0.80|$.

Statistical significance: ${ }^{*}$-value $<0.10,{ }^{* *}$-value $<0.05,{ }^{* * *} p$-value $<0.01$. 